https://nv.nltu.edu.ua

https://doi.org/10.36930/40310102

Article received 28.12.2020 p.

Article accepted 04.02.2021 p.

\title{
ОСНОВНІ ХАРАКТЕРИСТИКИ ТЕМПЕРАТУРНОГО РЕЖИМУ ПОВІТРЯ РОЗТОЧЧЯ В РОЗРІЗІ ТРИВАЛИХ І КОРОТКОЧАСНИХ ЗМІН
}

\begin{abstract}
Глобальне оцінювання температурного режиму нашої планети найповніше висвітлює Міжурядова група експертів зі зміни клімату (МГЕЗК) у періодичних звітах, де відзначено ріст температури повітря над поверхнею суші та океану у ХX та XXI століттях, який проявляється в різних місцях неоднаково. Як констатує МГЕЗК, проведення різних аналізів дає підставу припустити, що температури в північній півкулі за останне десятиліття були вищі, ніж у будь-який інший час за останні 6-10 століть. Відповідно до програми "Літопису природи заповідників і національних природних парків" в установах ПЗФ здійснюють локальні метеорологічні дослідження. У роботі наведено основні характеристики температурного режиму природного заповідника "Розточчя" за даними власної метеостанції за період з 2005 р. по 2019 р. включно. Відзначено, що найбільші відхилення температури повітря спостерігаються влітку $+2,5{ }^{\circ} \mathrm{C}$ та взимку $+2,2{ }^{\circ} \mathrm{C}$, менші - навесні та восени, відповідно $+1,8^{\circ} \mathrm{C}$ та $+1,7^{\circ} \mathrm{C}$. Аналіз середньомісячних температур у розрізі п'ятирічних періодів показує найістотніше підвищення температур періоду 2015-2019 рр., коли середні річні температури були вищими за 9,2 ${ }^{\circ} \mathrm{C}$. Середня річна температура досліджуваного п'ятнадцятирічного періоду зросла від 6,9 до $9,0{ }^{\circ} \mathrm{C}$, тобто на $2,1{ }^{\circ} \mathrm{C}$. Максимальні абсолютні відхилення зафіксовано в літні місяці, це від 2,1 до $3,0{ }^{\circ} \mathrm{C}$, що становить $12-18$ \% до середньої архівної температури сезону, а абсолютні мінімальні - навесні, від 1,3 до $2,4{ }^{\circ} \mathrm{C}$, тобто на $19-34 \%$ більше температури весни за даними архіву. Отже, наведені цифри демонструють чітку тенденцію до підвищення середньорічних і сезонних температур як для досліджуваного п'ятнадцятирічного періоду 2005-2019 pp. загалом, так і для всіх його п'ятирічних складових. Порівняння динаміки температур за календарними сезонами року показало стабільне підвищення температур за всіма сезонами порівняно з багаторічними архівними показниками. Також виявлено стійкий тренд підвищення суми ефективних температур (більше $\left.+5^{\circ} \mathrm{C}\right)$ за п'ятирічними періодами: за період 2010-2014 pр. збільшення становить 3,8 \%, а за 2015-2019 pp. - 6,6 \% порівняно з 2005-2009 pp.
\end{abstract}

Ключові слова: зміни клімату; середньодобова температура повітря; річна амплітуда; природний заповідник.

\section{Вступ}

Зміни клімату на нашій планеті відбувалися періодично - льодовикові періоди змінювалися періодом потепління, потім знову похолоданням. У минулому це були природні процеси, не пов'язані з діяльністю людини. За два останні століття науково-технічний прогрес досяг значних висот, втручання людини в біосферу набуло загрозливих масштабів, що, безумовно, пришвидшило зміни клімату. Викиди парникових газів в атмосферу промисловими підприємствами, транспортом, осушення боліт, збільшення за площею урбанізованих територій і зменшення площі стійких природних екосистем, здатних до самовідтворення - це далеко не всі чинники, що сприяють глобальним кліматичним змінам. Відповідно до програми "Літопис природи заповідників і національних природних парків" в установах ПЗФ ведуться локальні метеорологічні спостереження, які є основою фенологічних та біоценотичних досліджень. Спостереження за динамікою температурного режиму повітря в природному заповіднику "Розточчя" $є$ осно- вою локального кліматичного моніторингу, який дає змогу прослідкувати за відхиленнями в часовому виміpi, порівняти 3 глобальними кліматичними змінами i прив'язати його до фенологічних досліджень. Зміни середньодобової температури повітря впливають на сезонний розвиток рослин і тварин, спричиняють аномальні явища, такі, як повторне цвітіння, збільшують ризик захворюваності та ураження шкідниками, тому дослідження є актуальним.

Об'єкт дослідження - температурний режим повітря Українського Розточчя як основна характеристика змін клімату.

Предмет дослідження - кліматичні тренди, пов'язані зі змінами температурного режиму повітря.

Мета роботи - проаналізувати температурний режим повітря за даними метеостанції заповідника за період 2005-2019 pр. для виявлення короткочасних і довготривалих його змін на території Українського Розточчя.

Для досягнення зазначеної мети визначено такі основні завдання дослідження: проаналізувати тенденції

\section{Інформація про авторів:}

Стрямець Галина Володимирівна, канд. с.-г. наук, ст. наук. співробітник, заступник директора з наукової роботи.

Email: galina.stryamets@gmail.com; https://orcid.org/0000-0002-2491-6465

Гребельна Валентина Омелянівна, мол. наук. співробітник. Email: zaproz25@gmail.com

Скобало Оксана Степанівна, мол. наук. співробітник. Email: zaproz25@gmail.com

Цитування за ДстУ: Стрямець Г. В., Гребельна В. О., Скобало О. С. Основні характеристики температурного режиму повітря Розточчя в розрізі тривалих і короткочасних змін. Науковий вісник НлтУ України. 2021, т. 31, № 1. С. 14-19.

Citation APA: Stryamets, G. V., Grebel'na, V. E., \& Skobalo, O. S. (2021). Main characteristics of the air temperature Regime breeding in the section of long-term and short-term changes. Scientific Bulletin of UNFU, 31(1), 14-19. https://doi.org/10.36930/40310102 
змін середньорічних і сезонних температур для досліджуваного п'ятнадцятирічного періоду загалом і для його п'ятирічних складових; дослідити зміни річної амплітуди температури повітря, яка демонструє ступінь його континентальності та тренд суми ефективних температур, що відповідає за фенологічний розвиток.

Наукова новизна отриманих результатів дослідження - вперше для біосферного резервату "Розточчя" здійснено аналіз температурного режиму атмосферного повітря за п'ятнадцятирічний період (2005-2019 рр.) за даними метеостанції заповідника як в розрізі короткочасних, так і довготривалих змін, проаналізовано середньодобові, максимальні та мінімальні температури, встановлено закономірності росту середньодобової температури повітря та збільшення суми ефективних температур, що є підтвердженням потепління.

Практична значущість результатів дослідження отримані результати свідчать про зміни клімату в Українському Розточчі, прослідковується тренд потепління, що важливо врахувати в менеджменті сільського, лісового, садово-паркового господарствах.

Аналіз останніх досліджень та публікацій. Глобальне оцінювання температурного режиму нашої планети найповніше висвітлила Міжурядова група експертів зі зміни клімату (МГЕЗК), утворена в 1988 р. 3 часу свого створення МГЕЗК підготувала низку доповідей про наявну наукову та економічну інформацію щодо зміни клімату (1990, 1995, 2001, 2007 і 2013 рр.), які ми наводимо нижче. Середнє значення температури повітря біля поверхні суші і температури поверхні моря в період після 1861 р. підвищувалося. Темпи і тривалість потепління в XX ст., ймовірно, є найбільш значними, ніж у будь-які інші часи впродовж останніх 1000 років. У XX ст. це підвищення становило $0,6+0,2^{\circ} \mathrm{C}$, а на XXI ст. прогнозують не менше $1,8{ }^{\circ} \mathrm{C}$. Підвищення середньої температури на $2{ }^{\circ} \mathrm{C}$ означає їі зростання в деяких регіонах на $5{ }^{\circ} \mathrm{C}$ і менше. Причому, особливо сильні зміни швидше відбудуться на полюсах. За гіршим сценарієм, зростання середньої температури становитиме до $6{ }^{\circ} \mathrm{C}$, а в окремих місцях $-10-15{ }^{\circ} \mathrm{C}$, що означає кардинальні зміни клімату і багатократне збільшення частоти аномальних погодних явищ $[6,7,8,16$, 17]. Як констатує МГЕЗК, проведення різних аналізів дає підставу припустити, що температури в північній півкулі за останнє десятиліття були вищі, ніж у будьякий інший час за останні 6-10 століть. Дослідження здійснені внаслідок опрацювання непрямих даних, розрахунку різними методами, які дають змогу визначити клімат минулого за товщиною річних кілець дерев, використовуючи керни льоду, корали й інші непрямі дані 3 річним дозволом.

Нові аналізи максимальних добових температур на поверхні суші за період з 1950 по 1993 рр. продовжують свідчити про те, що міра добового діапазону температур зменшується в дуже багатьох точках земної кулі, хоча і не скрізь. У середньому мінімальні температури зростають приблизно в два рази швидше від максимальних температур $\left(0,2{ }^{\circ} \mathrm{C}\right.$ проти $0,1^{\circ} \mathrm{C}$ в десятиліття) $[8,9$, 16 , 17]. Окрім глобальних змін, спостерігаюся регіональні зміни клімату, про які свідчать численні наукові праці $[3,10,11,12,13,15,17]$.

Матеріали та методи дослідження. Метеостанція природного заповідника "Розточчя" розташована в пів- денній частині заповідника і в південно-східній частині території Українського Розточчя. Географічні координати 495'ㄷㄱ"N і 234ㄴ'884"Е, висота над рівнем моря 291 м.

Метеорологічні спостереження в ПЗ "Розточчя" здійснюють за методиками, рекомендованими програмою "Програма Літопису природи для заповідників та національних природних парків" [1]. Показники температури повітря, вологості, швидкість вітру фіксують кожні три години, кількість опадів - за добу. Оброблення та групування показників, отриманих на метеостанції, виконують так, щоб дати характеристику погоди за кожен місяць року, причому так, щоб ії можна було б подати за основними показниками за кожен день місяця. Ці показники потрібні для проведення цілорічних екологічних досліджень. Характеристика сезонів року (зими, весни, літа, осені) є основою і головним чинником фенологічного розвитку видів флори фауни та рослинних угруповань, зміни у неживій природі та ландшафтних комплексах. Критеріями початку та кінця цих періодів є термічні показники [1]. Статистичне оброблення даних - відповідно до методики Аргучинцевої (2007). Фенологічні спостереження ведуть відповідно до методики Шульца (1981), поділ на сезони і субсезони - за рекомендаціями Програми Літопису природи.

\section{Результати дослідження та їх обговорення}

Оскільки переважна більшість природних явищ безпосередньо зумовлені термічним режимом, то однією із основних кліматичних характеристик, які фіксують в заповіднику, є група показників температурного режиму повітря. Стаття показує динаміку цих показників за останній п'ятнадцятирічний період, а саме за 2005-2019 pp. Для більш поглибленого аналізу отриманих даних було виконано їх порівняння з багаторічними архівними даними за першу половину XX ст. [5]. Для цього обрано метеостанцію Рава-Руська, яка розташована у північній частині Українського Розточчя і відзначається кліматичними умовами, які максимально наближені до умов території заповідника. Порівняння динаміки температур за календарними сезонами року показало стабільне підвищення температур для всіх сезонів порівняно з багаторічними архівними показниками (табл. 1).

Табл. 1. Сезонні відхилення середньомісячних температур за період 2005-2019 рр. від багаторічних архівних даних

\begin{tabular}{|c|c|c|c|c|c|}
\hline \multirow{2}{*}{$\begin{array}{c}\text { Період } \\
\text { спостереження, } \\
\text { роки }\end{array}$} & \multicolumn{4}{|c|}{$\begin{array}{c}\text { Середньомісячний показник } \\
\text { у розрізі сезонів і місяців }\end{array}$} & \multirow{2}{*}{$\begin{array}{l}\text { Се- } \\
\text { реднє } \\
\text { за рік }\end{array}$} \\
\hline & \begin{tabular}{|c|} 
Весна, \\
III-V
\end{tabular} & \begin{tabular}{|c|} 
Літо, \\
VI-VIII \\
\end{tabular} & $\begin{array}{l}\text { Осінь, } \\
\text { IX-XI }\end{array}$ & $\begin{array}{l}\text { Зима, } \\
\text { I, II, XII }\end{array}$ & \\
\hline \multicolumn{6}{|c|}{$\begin{array}{c}\text { Метеостанція заповідника } \\
\text { (центральна частина Українського Розточчя) }\end{array}$} \\
\hline Середнє за 2005-2009 & $\frac{8,5}{+1,3}$ & $\frac{18,6}{+2,1}$ & $\frac{9,0}{+1,7}$ & $\frac{-1,2}{+2,1}$ & $\frac{8,7}{+2,2}$ \\
\hline Середнє за 2010-2014 & $\frac{9,0}{+1,8}$ & $\frac{19,0}{+2,5}$ & $\frac{9,0}{+1,7}$ & $\frac{-2,1}{+1,2}$ & $\frac{8,7}{+2,2}$ \\
\hline Середнє за 2015-2019 & $\frac{9,6}{+2,4}$ & $\frac{19,5}{+3,0}$ & $\frac{9,7}{+2,4}$ & $\frac{-0,2}{+2,1}$ & $\frac{9,7}{+2,8}$ \\
\hline Середнє за 2005-2019 & $\frac{9,0}{+1,8}$ & $\frac{19,0}{+2,5}$ & $\frac{9,1}{+1,7}$ & $\frac{-1,1}{+2,2}$ & $\frac{9,0}{+2,1}$ \\
\hline \multicolumn{6}{|c|}{$\begin{array}{c}\text { Метеостанція Рава-Руська } \\
\text { (північно-західна частина Українського Розточчя) }\end{array}$} \\
\hline $\begin{array}{l}\text { Середні за 1-шу по- } \\
\text { ловину XX ст. }\end{array}$ & 7,2 & 16,5 & 7,3 & $-3,3$ & 6,9 \\
\hline
\end{tabular}

Примітка: у чисельнику - середньомісячна температура в ${ }^{\circ} \mathrm{C}$; у знаменнику - відхилення від багаторічної архівної сезону або року в ${ }^{\circ} \mathrm{C}$. 
Дані табл. 1 свідчать про те, що найбільші відхилення температури повітря спостерігаються влітку $(+2,5$ $\left.{ }^{\circ} \mathrm{C}\right)$ та взимку $\left(+2,2{ }^{\circ} \mathrm{C}\right)$, менші - навесні та восени, відповідно $+1,8$ та $+1,7^{\circ} \mathrm{C}$.

Для території України головною характеристикою термічного режиму є середньомісячна температура повітря [3]. Як видно з отриманих даних, крива річного ходу середніх температур повітря досліджуваного періоду за формою значною мірою наближена до кривої багаторічних архівних даних (Рава-Руська, перша половина XX ст.) [5], але розташована дещо вище від останньої, що свідчить про стабільне підвищення середньомісячних температур упродовж усього року (рис. 1).

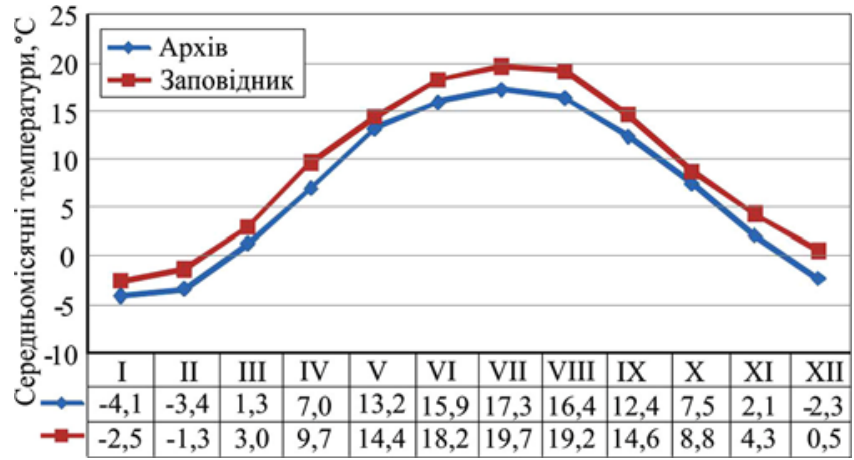

Рис. 1. Середньомісячні температури повітря за даними 2005-

2019 рр. порівняно з архівними (Рава-Руська метеостанція) [5]

Як результат, середня річна температура досліджуваного п'ятнадцятирічного періоду зросла від 6,9 до 9,0 ${ }^{\circ} \mathrm{C}$, тобто на $2,1{ }^{\circ} \mathrm{C}$. Таке відхилення від багаторічних даних не можна розглядати як щось аномальне. Так, за період 1900-1980 рр. значення середніх річних температур в Україні відхилялись від середнього в межах 2-2,5 ${ }^{\circ} \mathrm{C}$. Загалом за цей період у більшості районів відбулось пониження температури, яке відповідно супроводжувалось збільшенням річних сум опадів $[3,10,11]$.

Аналіз річного ходу максимальних і мінімальних температур показав, що вони аналогічні до ходу середніх температур, тобто, коли максимального значення температури досягають в літні місяці, а найнижчі показники спостерігаються в січні-лютому (рис. 2).

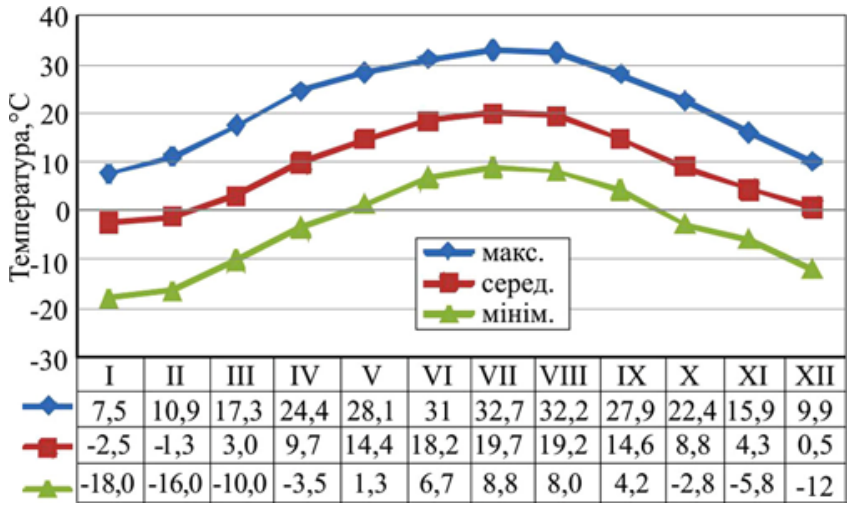

Рис. 2. Максимальні, середні, і мінімальні місячні температури повітря за період 2005-2019 pp.

Подамо усереднені місячні дані за 15 років: максимальна та мінімальна температури повітря і середньодобова місячна температура характеризують загалом тепловий режим кожного місяця в році. Максимальну температуру повітря в січні за досліджуваний період зафіксовано в 2007 р., яка становила $+11^{\circ} \mathrm{C}$, мінімальна в 2006 p. $-32{ }^{\circ}$ C. Максимальну температуру повітря в липні за досліджуваний період було зафіксовано в 2012 р., що становила $+35^{\circ} \mathrm{C}$, мінімальна - в 2019 р. $+5,4^{\circ} \mathrm{C}$ (табл. 2,3 ).

Табл. 2. Показники екстремальної мінімальної температури повітря за місяцями

\begin{tabular}{|c|c|c|c|c|c|c|c|c|c|c|c|c|}
\hline \multirow{2}{*}{ Рік } & \multicolumn{12}{|c|}{ Місяць } \\
\hline & I & II & III & IV & $\mathrm{V}$ & VI & VII & VIII & IX & $X$ & XI & XII \\
\hline 2005 & $-18,0$ & $-24,3$ & $-14,0$ & $-4,0$ & 2,5 & 5,2 & 8,6 & 10,6 & 4,0 & $-3,1$ & $-9,6$ & $-12,0$ \\
\hline 2006 & $-32,0$ & $-23,0$ & $-18,5$ & $-4,0$ & 6,0 & 2,9 & 9,8 & 6,5 & 5,0 & $-5,5$ & $-5,6$ & $-0,4$ \\
\hline 2007 & $-8,0$ & $-14,0$ & $-2,1$ & $-2,5$ & $-6,5$ & 7,5 & 8,5 & 7,0 & 2,0 & $-3,5$ & $-10,5$ & $-14,5$ \\
\hline 2008 & $-16,5$ & $-15,5$ & $-5,0$ & 0,0 & 3,5 & 7,5 & 9,5 & 9,5 & 5,0 & $-2,0$ & $-5,0$ & $-14,5$ \\
\hline 2009 & $-18,0$ & $-16,0$ & $-13,5$ & $-1,5$ & 0,5 & 5,0 & 9,5 & 7,5 & 4,5 & $-1,0$ & $-5,0$ & $-20,5$ \\
\hline 2010 & $-28,5$ & $-17,0$ & $-15,0$ & $-1,0$ & 7,5 & 7,0 & 10,0 & 6,5 & 3,5 & $-5,5$ & $-6,0$ & $-18,0$ \\
\hline 2011 & $-19,5$ & $-16,0$ & $-18,0$ & $-0,5$ & $-5,0$ & 9,0 & 9,5 & 8,0 & 3,0 & $-4,5$ & $-5,5$ & $-10,7$ \\
\hline 2012 & $-20,0$ & $-29,0$ & $-9,0$ & $-6,0$ & 4,0 & 6,8 & 10,0 & 7,0 & 3,0 & $-2,1$ & $-4,1$ & $-14,5$ \\
\hline 2013 & $-7,1$ & $-16,0$ & $-14,0$ & $-18,5$ & $-2,5$ & 6,2 & 8,0 & 9,5 & 8,5 & $-0,8$ & $-1,5$ & $-5,5$ \\
\hline 2014 & $-17,0$ & $-16,0$ & $-2,9$ & $-2,0$ & $-1,0$ & 7,0 & 10,9 & 8,0 & 1,9 & $-5,5$ & $-6,6$ & $-18,0$ \\
\hline 2015 & $-20,6$ & $-10,0$ & $-5,5$ & $-2,3$ & 0,7 & 8,0 & 7,0 & 7,2 & 3,0 & $-2,0$ & $-4,0$ & $-12,0$ \\
\hline 2016 & $-17,5$ & $-7,4$ & $-5,0$ & $-1,2$ & 3,5 & 5,0 & 9,0 & 7,0 & 5,0 & $-2,5$ & $-7,0$ & $-11,0$ \\
\hline 2017 & $-23,0$ & $-13,0$ & $-2,6$ & $-4,0$ & 0,0 & 7,0 & 8,0 & 7,0 & 4,0 & 0,0 & $-4,0$ & $-6,0$ \\
\hline 2018 & $-13,0$ & $-21,0$ & $-23,0$ & $-2,5$ & 6,0 & 8,0 & 9,0 & 11,0 & 9,0 & $-1,0$ & $-9,0$ & $-14,3$ \\
\hline 2019 & $-11,3$ & $-5,0$ & $-5,0$ & $-2,5$ & 0,5 & 8,5 & 5,4 & 8,0 & 2,0 & $-3,0$ & $-4,2$ & $-8,0$ \\
\hline Cep. & -18 & $-16,5$ & $-10,2$ & $-3,5$ & 1,3 & 6,8 & 8,8 & 8,0 & 4,2 & $-2,8$ & $-5,8$ & $-18,0$ \\
\hline
\end{tabular}

Табл. З. Показники максимальної температури повітря за місяцями

\begin{tabular}{|c|c|c|c|c|c|c|c|c|c|c|c|c|}
\hline \multirow{2}{*}{ Рік } & \multicolumn{12}{|c|}{ Місяць } \\
\hline & I & II & III & IV & V & VI & VII & VIII & IX & $\mathrm{X}$ & XI & XII \\
\hline 2005 & 10,8 & 5,5 & 16,1 & 21,0 & 31,0 & 28,0 & 32,9 & 26,7 & 26,5 & 20,8 & 13,3 & $\overline{5,5}$ \\
\hline 2006 & 3,7 & 10,0 & 13,0 & 22,0 & 25,0 & 30,5 & 30,7 & 28,5 & 25,0 & 24,1 & 17,5 & 5,7 \\
\hline 2007 & 11,0 & 9,0 & 17,5 & 23,0 & 31,0 & 30,0 & 35,0 & 33,5 & 25,0 & 23,0 & 11,0 & 7,0 \\
\hline 2008 & 9,0 & 17,5 & 16,0 & 20,5 & 27,0 & 30,0 & 33,5 & 32,5 & 32,2 & 20,0 & 19,0 & 10,0 \\
\hline 2009 & 7,1 & 14,0 & 17,0 & 26,5 & 28,0 & 30,5 & 32,5 & 30,5 & 27,0 & 24,5 & 13,0 & 11,5 \\
\hline 2010 & 2,0 & 9,5 & 19,5 & 23,5 & 24,5 & 33,0 & 33,0 & 32,5 & 23,0 & 16,0 & 19,8 & 8,5 \\
\hline 2011 & 7,5 & 9,5 & 18,5 & 23,0 & 28,5 & 31,0 & 32,0 & 29,0 & 28,0 & 21,0 & 12,5 & 12,5 \\
\hline 2012 & 7,5 & 5,5 & 18,4 & 29,0 & 30,0 & 33,0 & 35,0 & 35,5 & 28,0 & 21,5 & 17,0 & 6,5 \\
\hline 2013 & 5,5 & 5,5 & 13,0 & 27,5 & 28,0 & 31,5 & 33,5 & 34,0 & 23,0 & 22,2 & 18,5 & 13,6 \\
\hline
\end{tabular}




\begin{tabular}{|c|c|c|c|c|c|c|c|c|c|c|c|c|}
\hline 2014 & 9,5 & 11,0 & 21,0 & 23,0 & 28,0 & 29,0 & 31,0 & 33,0 & 26,4 & 25,5 & 20,0 & 11,0 \\
\hline 2015 & 10,0 & 13,0 & 20,0 & 25,0 & 27,0 & 31,0 & 34,5 & 36,0 & 35,0 & 22,5 & 16,0 & 13,0 \\
\hline 2016 & 9,5 & 15,0 & 16,0 & 25,0 & 29,0 & 32,0 & 32,0 & 32,0 & 30,0 & 23,0 & 11,0 & 7,3 \\
\hline 2017 & 3,0 & 16,0 & 20,0 & 24,0 & 28,0 & 31,0 & 32,0 & 35,0 & 28,0 & 23,0 & 14,0 & 13,0 \\
\hline 2018 & 10,0 & 9,0 & 15,0 & 26,0 & 30,0 & 31,0 & 29,0 & 31,0 & 30,0 & 24,0 & 19,0 & 8,0 \\
\hline Cep. & 7,3 & 10,8 & 17,3 & 24,0 & 27,9 & 30,7 & 32,6 & 31,9 & 27,5 & 22,1 & 15,8 & 9,5 \\
\hline
\end{tabular}

Мінімальні температури повітря - показник важливий для сільського та лісового господарства, особливо навесні, бо показує пізні заморозки, які відбувалися в травні в 2007, 2011, 2013 рр. і призводили до різної міри пошкодження лісових і сільськогосподарських культур.

Показник максимальної температури вказує на короткочасні потепління в зимові місяці, спеку в веснянолітній та осінній періоди. Найвищі максимальні температури взимку спостерігалися в січні 2007 р. та лютому 2008 р. Тривале потепління взимку порушує глибокий спокій багатьох видів рослин та тварин, знижуючи їх життєздатність.

Табл. 4. Середньомісячні показники температур повітря в ${ }^{\circ} \mathrm{C}$ за період 2005-2019 рр. та їх амплітуда

\begin{tabular}{|c|c|c|}
\hline Рік & Середнє за рік & Амплітуда \\
\hline 2005 & $\mathbf{8 , 0}$ & 19,2 \\
\hline 2006 & 8,3 & 29,2 \\
\hline 2007 & 9,2 & 22,0 \\
\hline 2008 & 9,1 & $\mathbf{1 8 , 9}$ \\
\hline 2009 & 8,8 & 23,1 \\
\hline Cep. 2005-2009 & 8,7 & 21,4 \\
\hline 2010 & 8,2 & 27,9 \\
\hline 2011 & 8,7 & 20,9 \\
\hline 2012 & 8,3 & $\mathbf{3 0 , 8}$ \\
\hline 2013 & 9,1 & 22,7 \\
\hline 2014 & 9,4 & 22,6 \\
\hline Cep. 2010-2014 & 8,7 & 23,7 \\
\hline 2015 & 9,9 & 21,3 \\
\hline 2016 & 9,3 & 23,0 \\
\hline 2017 & 9,2 & 26,1 \\
\hline 2018 & 9,9 & 23,5 \\
\hline 2019 & $\mathbf{1 0 , 2}$ & 24,4 \\
\hline Cep. 2015-2019 & 9,7 & 22,4 \\
\hline Cep. 2005-2019 & 9,0 & 22,2 \\
\hline
\end{tabular}

Примітка: потовщеним шрифтом виділено максимальні і мінімальні показники за весь період.

Зміна середньорічної температури повітря ілюструє зміни клімату. За досліджуваний період в заповіднику вона змінювалась від $+8,0$ до $+10,2{ }^{\circ} \mathrm{C}$, середнє багато- річне значення за досліджуваний період становить $+9,0$ ${ }^{\circ} \mathrm{C}$, це вище, ніж у попередніх дослідженнях: +7,0$7,8{ }^{\circ} \mathrm{C}$ [9], або $+7,5{ }^{\circ} \mathrm{C}$ [14]. Важливим показником клімату є річна амплітуда температури повітря, яка дає змогу встановити ступінь його континентальності. За архівними даними вона становить $21,4^{\circ} \mathrm{C}$. За дослідний період цей показник незначно зріс (на $1,0{ }^{\circ} \mathrm{C}$ ), хоча в окремі роки коливання сягали до $29,2-30,8^{\circ} \mathrm{C}$ (табл. 4).

Аналіз середньомісячних температур у розрізі п'ятирічних періодів (рис. 3) показує найістотніше підвищення температур періоду 2015-2019 рр., коли середні річні температури не опускались нижче $9,2{ }^{\circ} \mathrm{C}$. За це п'ятиріччя зафіксовано найвищі середньомісячні температури у 2012, 2015 pp. $-21,5{ }^{\circ} \mathrm{C}$, а також максимальну середньорічну температуру у 2019 p. $-10,2{ }^{\circ} \mathrm{C}$. Цей рік виявився не тільки найтеплішим, а і найсухішим за досліджуваний період [13].

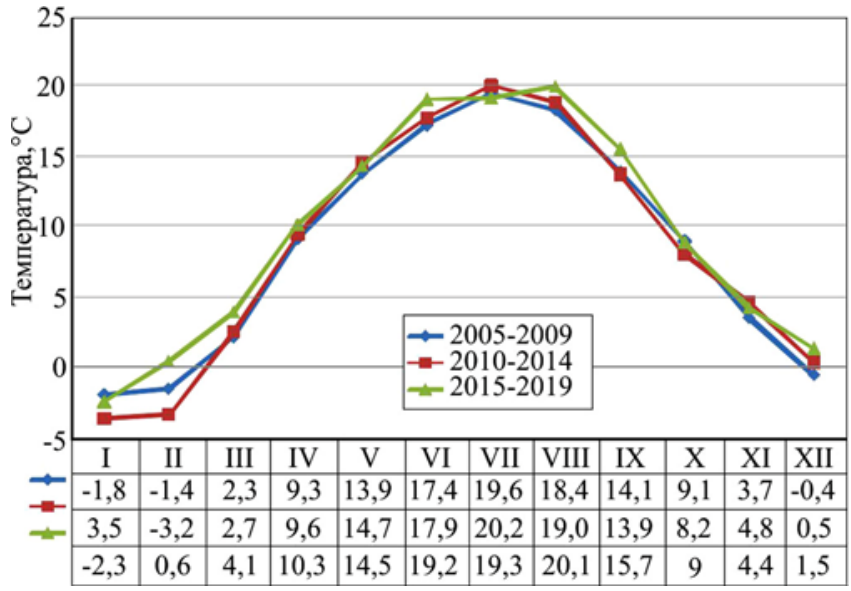

Рис. 3. Середньомісячні температури повітря за п'ятирічні періоди

Максимальні абсолютні відхилення зафіксовано в літні місяці, це від 2,1 до $3,0{ }^{\circ} \mathrm{C}$, що становить $12-18 \%$ до середньої архівної температури сезону, а абсолютні мінімальні - навесні, від 1,3 до $2,4{ }^{\circ} \mathrm{C}$, тобто на $19-34 \%$ більше від температури весни за даними архіву (табл. 5).

Табл. 5. Хід наростання ефективного тепла за місяцями за вегетаційні періоди 2005-2019 рр.

\begin{tabular}{|c|c|c|c|c|c|c|c|c|c|c|c|c|}
\hline Рік & II & III & IV & V & VI & VII & VIII & IX & X & XI & ХII & За період \\
\hline 1 & 2 & 3 & 4 & 5 & 6 & 7 & 8 & 9 & 10 & 11 & 12 & 13 \\
\hline 2005 & - & 34 & 263 & 414 & 468 & 448 & 543 & 430 & 270 & 82 & - & 2952 \\
\hline 2006 & - & - & 275 & 411 & 506 & 652 & 551 & 465 & 324 & - & - & 3184 \\
\hline 2007 & - & 142 & 259 & 492 & 574 & 609 & 595 & 368 & 251 & - & - & 3290 \\
\hline 2008 & 35 & 117 & 272 & 411 & 547 & 564 & 583 & 389 & 323 & 90 & - & 3331 \\
\hline 2009 & - & 7 & 324 & 427 & 521 & 633 & 576 & 456 & 244 & 156 & 23 & 3367 \\
\hline 2010 & - & 69 & 288 & 465 & 549 & 644 & 620 & 375 & 168 & 138 & - & 3316 \\
\hline 2011 & - & 51 & 297 & 437 & 555 & 598 & 595 & 468 & 229 & 44 & - & 3274 \\
\hline 2012 & - & 125 & 284 & 469 & 544 & 666 & 585 & 449 & 270 & 88 & - & 3480 \\
\hline 2013 & - & - & 263 & 477 & 557 & 582 & 586 & 343 & 299 & 52 & - & 3159 \\
\hline 2014 & 6 & 194 & 300 & 436 & 486 & 631 & 559 & 445 & 302 & 153 & - & 3512 \\
\hline 2015 & - & - & 250 & 420 & 542 & 613 & 666 & 474 & 238 & 44 & - & 3247 \\
\hline 2016 & - & 120 & 315 & 452 & 569 & 608 & 575 & 471 & 223 & 45 & - & 3378 \\
\hline 2017 & - & 169 & 255 & 437 & 561 & 591 & 631 & 428 & 294 & 34 & - & 3400 \\
\hline 2018 & - & - & 421 & 535 & 557 & 603 & 623 & 553 & 238 & 64 & - & 3673 \\
\hline 2019 & - & 166 & 301 & 410 & 645 & 582 & 615 & 439 & 325 & - & - & 3483 \\
\hline Середнс & $\mathbf{3}$ & $\mathbf{7 9}$ & $\mathbf{2 9 1}$ & $\mathbf{4 4 6}$ & $\mathbf{5 4 5}$ & $\mathbf{6 0 1}$ & $\mathbf{5 9 3}$ & $\mathbf{4 3 7}$ & $\mathbf{2 6 6}$ & $\mathbf{6 6}$ & $\mathbf{1}$ & $\mathbf{3 3 3 6}$ \\
\hline
\end{tabular}


Важливим показником для фенологічного розвитку рослин $є$ сума ефективних температур (більше $+5{ }^{\circ} \mathrm{C}$ ), яка для багатьох видів рослин у дикій природі є початком вегетаційного періоду. У табл. 5 наведено хід наростання ефективного тепла, обчислений за датами стійкого переходу середньої добової температури повітря через $+5{ }^{\circ} \mathrm{C}$.

Не важко помітити поступове збільшення суми ефективних температур, хоча з року в рік показники динамічно коливаються. Стійкий тренд виявляється за п'ятирічними періодами. Встановлено, що за період 2005-2009 pp. середнє значення суми ефективних температур становить $3224,8{ }^{\circ} \mathrm{C}$, за період 2010-2014 pp. $3348,2{ }^{\circ} \mathrm{C}$, за період $2015-2019$ pp. $-3436,2{ }^{\circ} \mathrm{C}$, тобто за другий період збільшення становить $3,8 \%$, а за третій 6,6 \% порівняно $з$ першим.

Такі тривалі систематичні зміни температурного режиму повітря не можуть не впливати на життєдіяльність живих організмів наземних екосистем. I хоча реакція рослин на температурний фактор може відзначатись досить широкою амплітудою, в умовах, коли відхилення від тривалих усталених параметрів набувають стабільності, для підтримання життєдіяльності організму щораз більшої ваги починають набувають інші метеорологічні фактори, серед яких слідом за температурою потрібно назвати кількість опадів, яка в умовах нашого регіону є основним джерелом забезпечення рослин вологою.

\section{Висновки}

Проаналізовано температурний режим повітря за даними метеостанції природного заповідника "Розточчя" за період 2005-2019 pр., що дало змогу виявити короткочасні та довготривалі його зміни на території Українського Розточчя. За результатами дослідження можна зробити такі основні висновки:

1. Аналіз температурних показників повітря в регіоні Розточчя показує тенденцію до підвищення середньорічних і сезонних температур як для досліджуваного п'ятнадцятирічного періоду 2005-2019 рр. загалом, так і для всіх його п'ятирічних складових.

2. Важливим показником клімату є річна амплітуда температури повітря, яка демонструє ступінь його континентальності. За дослідний період цей показник зріс на $1,0{ }^{\circ} \mathrm{C}$ і становить $22,4{ }^{\circ} \mathrm{C}$, в окремі роки коливання сягали до $29,2-30,8^{\circ} \mathrm{C}$, тобто клімат стає більш континентальний.

3. Результати метеорологічних спостережень у заповіднику свідчать про поступове збільшення суми ефективних температур. Стійкий тренд виявляється за п'ятирічними періодами: за період 2010-2014 рр. збільшення становить 3,8 \%, за період 2015-2019 pр. - на 6,6 \% порівняно $з$ першим.

\section{References}

1. Andriienko, T. L. (Ed.), Popovych, S. Yu., Parchuk, H. V., et al. (2002). Prohrama Litopysu pryrody dlia zapovidnykiv ta natsionalnykh pryrodnykh parkiv: metod. posibn. Kyiv: Vyd-vo "Akademperiodyka", 103 p. [In Ukrainian].

2. Arguchintceva, A. A. (2007). Metody statisticheskoi obrabotki $i$ analiza gidrometeorologicheskikh nabliudenii: uchebnoe posobie. Irkutsk: Izdatelstvo Irkutskogo Gosudarstvennogo universiteta, 106 p. [In Russian].

3. Babichenko, V. M., \& Zuzuka, F. V. (1998). Klimat Lvova. Lutsk, 346 p. [In Ukrainian].

4. Dazho, R. (1975). Osnovy ekologii. Moscow: Progress, 315 p. [In Russian].

5. Dovidnyk. (1959). Ahroklimatychnyi dovidnyk po Lvivskii oblasti. Kyiv: Derzhvydav silhosp. lit-ry URSR, 95 p. [In Ukrainian].

6. Entsyklopediia. (1990). Heohrafichna entsyklopediia Ukrainy. Vol. 3. Kyiv: URE, 480 p. [In Ukrainian].

7. IPCC. (2018). Summary for Policymakers of IPCC Special Report on Global Warming of $1.5^{\circ} \mathrm{C}$ approved by governments. Retrieved from: https://www.ipcc.ch/pdf/session48/pr_181008_P48_spm_en.pdf

8. Izrael, Iu. A., Gruza, G. V., Kattcov, V. M., \& Meleshko, V. P. (2001). Izmeneniia globalnogo klimata. Rol antropogennykh vozdeistvii. Meteorologiia i gidrologiia, 5, 5-21. [In Russian].

9. Kosik, L. B., \& Skobalo, O. S. (2006). Klimatichna ta fenologichna kharakteristika prirodnogo zapovidnika "Roztochchia". Mizhvidomchii naukovo-tekhnichnii zbirnik Natcionalnogo lisotekhnichnogo universitetu Ukraini. Forestry, Forest, Paper and Woodworking Industry, 32, 82-86. [In Ukrainian].

10. Krivoruchenko, Z. R. (2014). Tendentcii ta mozhlivi naslidki globalnikh ta regionalnikh zmin klimatu. Dnipropetrovskii derzhavnii agrarno-ekonomichnii universitet. Derzhavne upravlinnia: udoskonalennia ta rozvitok. Elektronne naukove fakhove vidannia, 9. Retrieved from: http://www.dy.nayka.com.ua. [In Ukrainian].

11. Litopis prirodi. (2020). Prirodnii zapovidnik "Roztochchia", cmt. Ivano-Frankove, 2005-2019. Kn. 24-33. [In Ukrainian].

12. Matolych, B. M. (Ed.), et al. (2009). Pryrodni resursy Lvivshchyny. Derzhavne upravlinnia okhorony navkolyshnoho pryrodnoho seredovyshcha $v$ Lvivskii oblasti. Lviv: PP Lukashchuk, V. S., 113 p. [In Ukrainian].

13. Priroda. (1984). Priroda Ukrainskoi SSR. Klimat. Kyiv: Naukova dumka, 232 p. [In Russian].

14. Prots-Kravchuk, H. L. (1972). Klimat. Pryroda Lvivskoi oblasti, (pp. 40-58). Lviv: Vyd-vo Lvivskoho un-tu, 340 p. [In Ukrainian].

15. Skobalo, O., Horban, I., \& Hrebelna, V. (2013). Fenoklimatychna periodyzatsiia v zapovidnyku "Roztochchia". Visnyk of Lviv university. Biological series, 63, 98-109. [In Ukrainian].

16. Stocker, T. F., Qin, D., Plattner, G.-K., Tignor, M., Allen, S. K., Boschung, J., Nauels, A., Xia, Y., Bex, V., \& Midgley, P. M. (Eds.) (2013). IPCC, Climate Change 2013: The Physical Science Basis. Contribution of Working Group I to the Fifth Assessment Report of the Intergovernmental Panel on Climate Change Cambridge University Press, Cambridge, United Kingdom and New York. NY, USA, 1535 p.

17. Striamets, H. V., Hrebelna, V. O., \& Skobalo, O. S., Striamets, S. P. (2018). Lokalni proiavy zmin klimatu na prykladi pryrodnoho zapovidnyka "Roztochchia". Scientific Bulletin of UNFU, 28(11), 24-28. https://doi.org/10.15421/40281104

G. V. Stryamets, V. E. Grebel'na, O. S. Skobalo

Nature Reserve "Roztochya", Ivano-Frankove, Ukraine

\section{MAIN CHARACTERISTICS OF THE AIR TEMPERATURE REGIME IN ROZTOCHIA CONSIDERING OF LONG-TERM AND SHORT-TERM CHANGES}

Climate change on our planet has occurred periodically and naturally. However, the anthropogenic impact is very significant recently causing climate change. The study of the temperature regime in the reserve is an urgent task, which allows following the deviations in time and links it to the phenological observations. In accordance with the program "Chronicles of the Nature of Reserves and National Nature Parks" local meteorological research is carried out in Roztochia Nature Reserve. The paper presents the main 
characteristics of the temperature regime of Roztochia Nature Reserve according to the data of its own meteorological station for the period from 2005 to 2019. Meteorological station of Roztochia Nature Reserve is located in the southern part of the reserve and in the south-eastern part of the territory of Ukrainian Roztochia. Geographic coordinates are $49^{\circ} 54^{\prime} 617^{\prime \prime} \mathrm{N}$ and $23^{\circ} 44^{\prime} 884^{\prime \prime} \mathrm{E}$, at $291 \mathrm{~m}$ above sea level. According to the literary sources review made, the global assessment of the temperature regime of our planet is most fully covered by the Intergovernmental Panel on Climate Change (IPCC) in periodic reports, which noted an increase in air temperature over the land and ocean in the $20^{\text {th }}$ and $21^{\text {st }}$ centuries, which manifests itself differently in different places. In addition to global change, there is regional climate change, as evidenced by numerous scientific papers. The results of our research show that the greatest deviations in air temperature are observed in summer $+2.5^{\circ} \mathrm{C}$ and in winter $+2.2{ }^{\circ} \mathrm{C}$, less in spring and autumn, respectively $+1.8^{\circ} \mathrm{C}$ and $+1.7^{\circ} \mathrm{C}$. The analysis of average monthly temperatures in the context of five-year periods shows the most significant increase in temperatures for the period 2015-2019, when the average annual temperatures were above $9.2{ }^{\circ} \mathrm{C}$. The average annual temperature of the 15 -year period under study increased from $6.9^{\circ} \mathrm{C}$ to $9.0^{\circ} \mathrm{C}$, that is, by $2.1^{\circ} \mathrm{C}$. The maximum absolute deviations were recorded in the summer months, it is from 2.1 to $3.0^{\circ} \mathrm{C}$, which is $12-18 \%$ of the average archived temperature of the season, and the absolute minimum - in the spring, from 1.3 to $2.4{ }^{\circ} \mathrm{C}$, t.e. $19-34 \%$ more than the spring temperature according to the archival data. Thus, the given figures demonstrate a clear tendency of an increase in average annual and seasonal temperatures both for the investigated fifteen-year period 2005-2019 as a whole, and for all its five-year periods. We have drawn the conclusions, that the results presented in the work demonstrate a clear trend of increasing average and seasonal temperatures both for the studied fifteen-year period 2005-2019 as one period, and for all its five-year components. Comparison of the temperature dynamics for the calendar seasons of the year showed a constant increase in temperatures for all seasons in comparison with the long-term archived indicators. Moreover, a constant trend of an increase in the sum of effective temperatures (more than $+5{ }^{\circ} \mathrm{C}$ ) was found for five-year periods: for the period 2010-2014. The increase is $3.8 \%$, and for 2015-2019-6.6\% compared to 2005-2009.

Keywords: climate change; average daily air temperature; annual amplitude; nature reserve; Roztochia Nature Reserve. 